\title{
The Words of Poems are Who You were: Contradictions and Continuities in Signs of Childness in Children's Books
}

\author{
Debbie Pullinger ${ }^{1}$
}

Published online: 5 February 2019

(c) The Author(s) 2018

\begin{abstract}
In Hollindale's Signs of Childness in Children's Books (1997), the idea that adulthood is continuous with childhood co-exists with the idea that it is forever separated. Far from being self-contradictory, this reflects the complex reality represented within children's literature. Focusing on the case of children's poetry, in which the relationship between adult and child is characteristically different from that in other forms, I examine how those relationships may occur differently, what children's poetry seeks to do in language, and how it relates to the body and to time. From this poetic perspective on what Hollindale describes as the "meaningful continuity between the child and adult self", I argue that in the absence of the constraints of narrative, with its linear progression and child protagonist, a particular kind of childness becomes evident.
\end{abstract}

Keywords Children's poetry $\cdot$ Poetry $\cdot$ Childness $\cdot$ Peter Hollindale $\cdot$ Carol Ann Duffy $\cdot$ Iain McGilchrist

Hollindale's proposed definition of children's literature in Signs of Childness in Children's Books (1997, p. 32) includes the suggestion that "it cannot be said too strongly that retaining the child in yourself is not the same thing as being a child ... we may be able to reconstruct a child of the mind and imagination, but childhood itself is over". He says, too, that there is "meaningful continuity between the child and adult self", and that "to keep the child in ourselves is not an eccentricity of children's writers but the common human lot" (p. 49). So within this slim volume,

Debbie Pullinger is a Fellow at Wolfson College, University of Cambridge. She teaches on Children's Literature courses at the Faculty of Education, and her monograph, From Tongue to Text: A New Reading of Children's Poetry, was published by Bloomsbury Academic in 2017. She ran the Poetry and Memory Project (2012-2016) and continues to research the value and experience of memorized and performed poetry.

Debbie Pullinger

dp371@cam.ac.uk

1 University of Cambridge, Cambridge, UK 
the idea that adulthood is continuous with childhood co-exists with the idea that it forever separated; the boundaries are simultaneously existent and nonexistent, real and unreal, precise and imprecise.

Noting this apparent disagreement, Rudd (2018) has said that Hollindale's argument is protean and divergent to the point of internal contradiction. To me, however, this is a sign of someone grappling with an intricate, multifaceted reality that refuses a single explanatory theory. Signs of Childness acknowledges that there is a course to be steered between, on the one hand, the idea that not only childhood itself, but aspects of childhood-in particular, the presentness of childhood-are lost to the adult, and, on the other, the idea that something of childhood is recoverable. Both continuity and boundary are part of the picture.

Ever since Rose argued for the "impossibility" of knowing the real child (1984), children's literature scholarship has been inclined to focus on the discontinuities and rifts. Within this line of reasoning, children are inevitably seen not only as completely different from adults, or wholly Other, but as different in predominantly disadvantageous ways. One reason this approach has proved so attractive is that it produces interesting problems into which critics can get their teeth. Thus, a significant strand of children's literature criticism focuses on relations of power, on antipathy, and on the interpellating effects of language. The result, as with the application of critical theory in any field, is a negative bias (e.g. Bennett 2001). Moreover, if it offers no remedy for the ills it opposes, this approach to scholarship can leave us, the writing adults, in an invidious position. As Coats pointed out some years ago (2001), we need to realize that there is a limit to the analogy of colonization, and that our appropriation of discourses is, or could be, mutual, intertextual, pluralist and polyphonic.

For a more complete picture that better reflects a complex reality, negative aspects can be held in tension with positive ones such as empathy, relations of human love and the creative effects of language. Such work is hard to do and even harder to have taken seriously. No one wants to look as if they have lost touch with their critical faculties. In the words of Gubar's article title, talking about actual children is a "Risky Business" (2013). But Gubar and others (e.g. Tatar 2009; Waller 2010) have taken that risk. There are signs of the deficit model being challenged by others; of fuller, more nuanced accounts that allow for continuities and for positive dynamics such as love and empathy. The developing field of cognitive poetics, for example, has reasserted the part played by certain biological realities, whilst Gubar's "kinship model" which "indicates relatedness, connection and similarity, without implying homogeneity, uniformity, and equality" (2013, p. 453) admits the continuities along with the boundaries.

Perhaps the "impossibility" argument has ignored the variety across textual forms or-as in The Case of Peter Pan (Rose 1984), which argues from a piece of children's theatre-has largely ignored the specific conditions and implications of the form under consideration (Gubar 2013). This is important because the role and participation of both artist and audience, and their relationship, is characteristically different within different art forms. In this article, I shall consider the case of children's poetry, and in particular one children's poem, to discover whether and how those relationships may occur differently. Focusing on what the 
poem seeks to do in language, and how it relates to the body and to time, I will offer a specifically poetic perspective on the potential existence and nature of, as Hollindale puts it, "meaningful continuity between the child and adult self" (1997, p. 49).

\section{Reopening the Case for Continuity}

As Hollindale observes, the desire to value a residual childhood in adult life is widespread and deep-rooted. Whilst we have literary evidence for this desire dating as least as far back as the 17th century, it is widely regarded as an invention of the Romantics, for whom the recovery of certain faculties of childhood was a central project. This recovery, however, has come to be regarded by children's literature theorists as problematic at best: Hollindale goes on to say that whilst we may be able to reconstruct childhood, "its presentness is irrecoverable" (1997, p. 22, italics original). One difficulty with Hollindale's argument is that notions of "continuity" and "retaining the child within", and the "presentness" of childhood, are not explicitly defined or differentiated. The supposition appears to be that the adult no longer has access to the modes of perception and thought experienced as a child, and that memories of childhood are either unreliable or inflected by subsequent experience, or both.

To deal first with the issue of memory, the unreliable nature of our recollections is borne out by a body of psychological research which demonstrates that all memories are reconstructions of events; that each subsequent recall is a reconstruction of the memory rather the event itself; and that we can quite easily be induced to create false memories. (The reconstructive nature of memory was first suggested by the work of Frederic Bartlett; a great number of researchers have since contributed to this line of thinking, such as Antonio Damasio, Daniel Schacter and Martin Conway.) Proof, perhaps, that I cannot really remember what it was like to be a child. But proof, in that case, that I may not necessarily recall accurately what it was like being me last Tuesday. Nevertheless, the operation of memory is important, and I will return to it in due course.

Regarding modes of perception and cognition, findings from neuroscience indicate that the way we experience the world as children is qualitatively different as a result of physiological differences (see Nikolajeva 2018, in this issue, for more ample discussion). We now know, for example, that young children have a greater concentration of receptor neurons, which results in a more intense sensory experience of the world. And now it appears that not only our perception but our entire cognitive processing is distinctively different when we are children. Iain McGilchrist's (2009) seminal work on the two cerebral hemispheres suggests that the qualities which the Romantics saw as the virtues of childhood-immediacy of experience, a feeling of connection with the world and things in it, an affinity with living beings, a different sense of time, lack of self-consciousness-are all qualities associated with the right cerebral hemisphere. It was, says, McGilchrist, who is both a neuroscientist and literary scholar, "this authentic 'presencing' of the world that Romantic poetry aimed to offer" (McGilchrist 2009, p. 359). Crucially, childhood, too, is associated with a 
greater reliance on the right cerebral hemisphere. The implication is therefore that the perceived, or perhaps remembered, difference in the child's lived experience has a solid basis in neurological reality.

This quality, or cluster of qualities, of childhood experience seems to me to have much in common with Hollindale's proposed attribute of childness, as helpfully distinguished from the pejorative childishness or childlikeness. But the qualities are not, on this account, forever lost in adulthood. For, whilst it substantiates the idea that childhood experience and adult experience are different, this evidence from neuroscience also allows for continuity. Although our matured, adult brains tend to rely more on left-hemisphere processes, our right hemispheres are still very much in use and playing a significant role in certain types of cognition. Moreover, accounts of and by individuals who have suffered impairment of the left hemisphere describe a lived experience that chimes closely with that of the Romantic ideal (see for example Bolte Taylor 2009.) It is an experience typically characterized as one of "presentness"- - which is indeed a very right-hemisphere sort of word-so something of the "presentness" of childhood may be recoverable, after all.

\section{Childness and the Poetic}

McGilchrist's understanding of brain laterality also casts new light on our understanding of language. Whilst it cannot be stressed strongly enough that both sides of the brain are involved in all aspects of cognition, it is predominantly the right hemisphere through which music, emotion, metaphor, connotation, ambiguity-in other words all the elements of poetic language - are processed and understood. Notions about language being processed by the left hemisphere, which persist in pop-psychology, are founded on a very limited understanding of a complex situation. There are therefore neurological grounds for saying that childhood and the poetic are connected by and within the right cerebral hemisphere. As I have argued elsewhere (Pullinger 2017), the connections between poetry and childhood run deep, and part of that connection appears to lie within the brain. So then, if we are seeking evidence of connection and continuity between adult and child within literature, poetry might be a good place to start.

Although poetry and drama written for children are beginning to attract more critical attention, narrative texts are still the case upon which most general children's literature theory is based. There may be some justification for this in that narrative fiction accounts for a large proportion of what is written, published and read as children's literature. Poetry, on the other hand, is the mode in which many children still have their first encounter with verbal art. And since the relationship between the text and the child (whether real or constructed) is different in a poem, it offers an alternative and hitherto largely overlooked perspective on the relationships amongst text, author and child - and another way of thinking about the idea of childness.

One indicator of that difference is the presence of the child protagonist, which, Hollindale argues, alone "is characteristic of children's literature as a genre" (1997, p. 39). Leaving aside the problem of taking prose fiction as the model for all children's 
literature, it is true that in most children's narrative texts the constructed child character looms large. Nodelman, in that other field-defining work, The Hidden Adult (2008), ratifies it as a defining trait, and further suggests that children's literature is normally focalized through a child (or childlike protagonists, such as animal child-surrogates.) The disruptive fact, however, is that many children's poems are signally devoid of children. As an exercise within my own doctoral research — an investigation of a corpus that comprised the complete work of seven British children's poets-I coded every poem according to whether there was child protagonist, child speaker or child addressee. This revealed that nearly three-quarters of the poems $(771$ out of 1,101$)$ had no child figure. So if children's poetry has any signs of childness, they generally do not inhere in the child protagonist. Hollindale, certainly, allows for the possibility of a child-free childness, saying, in one of his near-contradictions, that there are some texts which are "a masterpiece of childness without young children" (1997, p. 110).

Another essential property of children's literature noted by Hollindale is "the aesthetic of linear narrative" (1997, p. 66). Clearly this observation arises from the fact that, as already noted, theorists have concentrated on narrative texts; but it relates, too, to the child protagonist. Concern with the protagonist's progress through the external world and through time, with their processes of growth and development, means that children's novels and picturebooks tend towards linearity.

Whilst their applicability to the full spectrum of children's literature may be questioned, it is interesting to note that these proposed traits relate to structures that characterize the texts as narrative. What children's poetry therefore offers is the possibility of discovering how those traits, or perhaps "signs of childness," may be manifested outside the conditions of narrative. We might also speculate that in a poem, those traits or signs might relate to the child in precisely those aspects that characterize it as poetry.

So what "signs of childness" can we detect in such a poem?

The words of poems

The words of poems are nails

which tack the wind to a page,

so that the gone hour

when your kite pulled you over the field

blows in your hair.

Here are the opening lines of "The Words of Poems", chosen by Duffy to open her volume of New and Collected Poems for Children (2009). It sounds a keynote, in the original, musical sense of that phrase: the note that forms the basis of the musical scale and which sets the tone for the ensuing performance. As such, it offers a poetic observation on the nature of children's poetry.

\section{Language and Thought}

If narrative is telling stories, poetry, it might be said, is simply telling. The poem tells of the poet's thoughts and feelings; it represents some aspect of the poet's sensibility. Sometimes poems are concerned with the way in which the telling tells, and this is a theme taken up explicitly by many children's poets. In this, effectively her 
prologue, Duffy purposefully sets out poetry's stall for the child reader, demonstrating, through use of poetic strategies, what poetry can do and how it does it.

To restate the obvious, the poem is not narrative; there is no protagonist, and no unfolding of events. Instead, it grapples with ideas, which might be summarized as the nature of poetic language and the phenomenology of poetic experience. Through a series of images, some quite surprising, it ponders the mystery of language, its relationship to lived experience and its peculiar power to conjure up the memory of that experience. Implicit within this poetic meditation is a perspective on the operation of time, which is a crucial point of difference between narrative fiction and poetry. Narrative, as essentially a series of unfolding events, is concerned with movement through time. Lyric steps out of the stream of time in order to make sense of an event, an experience, a moment, a feeling, and strives to convey that sense by marshalling all the resources of poetic language. "The Words of Poems" does this most conspicuously through poetry's dominant mode of metaphor. Nails that try to pin down the wind, tears reflected in a mirror, small change in a purse, fishing nets scooping up sprats and tiddlers, goldfish in bags at the fair: images of capture and holding cascade across the page, creating a sense of poetry's workings and possibilities. But like the sprats and tiddlers, the images are also slippery. Sometimes the words of poems are the thing that catches (the mirror, the fishing net) and sometimes they are the thing caught (the stars, the goldfish). Thus it reflects the idea that poetic language is a means to recreate memory, and can itself become a memory with the potential for recreation.

Like a young child, the poem takes an experimental, provisional approach to language; it enjoys generating imaginative variations on theme; it plays a game of "what if". And like a young child, it does not take words for granted, but understands them as something to be investigated. So if there is childness in this children's poem, or indeed any children's poem, it might be found in the way that it conveys experience through language, and simultaneously highlights the relationship between the lived experience and the language. The obvious problem for the present argument is that this could be said of all poetry. But that, in fact, is what poets have been saying all along. Continuing a line stretching back to the Romantics, poet Michael Donaghy writes, "what makes us recognize a piece of writing as a poem is often a 'technique' whereby poets imitate children's thinking". Indeed, he says, "In one sense, all poetry is kids' stuff" (2005, p. xii).

\section{Embodiment}

The words of poems capture so that "the gone hour ... blows in your hair". As the line suggests, poetry has the power to reconstruct memory, even a memory of embodied sensation. Next to lived experience, language may seem as crude as nails, or at least very much like what T. S. Eliot referred to as "shabby equipment always deteriorating" (Eliot 1933). But poetic language has this power because it is also a primal language. It consists not merely of arbitrary, abstract symbols, but is instead rooted in music and form, and thereby in the body. The sense of the words may therefore be apprehended not only through semantic interpretation by the mind, but 
through sound and through the body also. Poetry and the sounds of poetic language are therefore able to return the child to the place where language and the body are felt not as irreconcilable facets of experience but as fundamentally interconnected (see Coats 2013; Pullinger 2017). They reassure children (and indeed all of us) that what we give and receive in language is neither accident nor artifice, but is in some way deeply connected to our embodied nature.

Secondly, then, the childness of children's poems inheres in their relationship with sound and the body. And the way that primal, poetic language evokes an active, embodied response to the formal, acoustic and kinaesthetic aspects, as well as an empathic response to the non-formal semantic elements, has significant implications for poems whose readers' relationship with the world and with language are in the early stages of development and deeply involve the body.

\section{Time}

The meanings of a poem, even a children's poem, are not always lying about on its surface. Duffy hints in this one that to make meaning of a poem-this poem included-we have to join the dots ourselves.

\section{The words of poems}

are stars, dot-to-dots of the Great Bear,

the Milky Way your telescope caught;

The words shine like stars; the shapes are made by the reader. But it may take time for the shapes to emerge; slow-release meanings may be activated by rereadings, by peformance or by subsequent life experience. In the meantime, the form of the poem and the music of poetic language-its prosody_hold us and contain our unknowing, even as they lead us towards new understandings. So although a poem is in the business of capturing a moment or series of moments, the poem itself is far from momentary. Rereading, as Collins argues (1991), is its default mode. That is where its rewards are reaped and, as with music, where pleasures intensify. Poems are also inherently and purposefully memorable, and so a poem encountered in childhood may well be given the chance to unfold its meaning and significance over time. As we discovered in a recent project to investigate the experience of the memorized poem, children may often enjoy (even if they do not fully comprehend) adult poems, and many adults carry a childhood poem through life, finding ever greater rewards (Pullinger and Whitley 2017).

So the third distinctive aspect of children's poetry's childness is bound up with its temporality. In a narrative, the meaning and significance unfold through the time of the story. In a poem, those things may unfold only partially on a first reading; the rest may or may not follow over time. This movement itself reflects an aspect of child consciousness. As children we are acutely aware of our partial understanding, but also live in the belief that we will know more, we will come to a fuller understanding - and look forward to that. We live in a kind of faith. Many poems - poems 
that, as the poet Glyn Maxwell puts it, "are worth the candle" (2012, p. 43)—are encountered in faith.

One implication of all this is that if meaning-making is distributed through the mind and the body, and across time, then the implied reader is necessarily a rather more indistinct figure. So then, if "the words of poems are who you were," what do we understand by that "you"? Is it an adult or a child? Since ambiguity is a vital poetic strategy, it seems reasonable to have it both ways. For an adult, the final note sounds wistful or nostalgic. For a child, the words may not have such a strong sense of poignancy, but children, too, are keenly aware of their own growth and of the loss of earlier stages of infancy. Additionally, the poem also looks forward to the child's future, when the poem will be who you were.

The words of poems

are coins in a poor man's hat; the claws of a lost cat.

The words of poems are who you were.

\section{The Words of Poems are Who You Were}

As I have attempted to demonstrate through this brief analysis, poetry offers a very different set of reading conditions from those of narrative, and one in which those boundaries are conspicuously and characteristically fluid. For children's poetry, these conditions set up a different kind of relationship between the adult and the child from those of narrative, and create possibilities of continuities and kinship. And in the absence of the constraints of narrative, with its linear progression and child protagonist, a particular kind of childness becomes evident. This is not to say that the childness of children's poetry is confined to children's poetry. It could also offer new perspectives on the childness of children's narrative fiction, as well as rounding out our understanding of children's literature more generally.

Open Access This article is distributed under the terms of the Creative Commons Attribution 4.0 International License (http://creativecommons.org/licenses/by/4.0/), which permits unrestricted use, distribution, and reproduction in any medium, provided you give appropriate credit to the original author(s) and the source, provide a link to the Creative Commons license, and indicate if changes were made.

\section{References}

Bennett, Jane. (2001). The Enchantment of Modern Life: Attachments, Crossings and Ethics. Princeton \& Oxford: Princeton University Press.

Bolte Taylor, Jill. (2009). My Stroke of Insight. London: Hodder.

Coats, Karen. (2001). Keepin' it plural: children's studies in the academy. Children's Literature Association Quarterly, 26(3), 140-150.

Coats, Karen. (2013). The meaning of children's poetry: a cognitive approach. International Research in Children's Literature, 6(2), 127-142.

Collins, Christopher. (1991). The Poetics of the Mind's Eye: Literature and the Psychology of Imagination. Philadelphia: University of Pennsylvania Press.

Donaghy, Michael. (2005). Introduction. In Michael Donaghy (Ed.), 101 Poems About Childhood. London: Faber. 
Duffy, Carol Ann. (2009). New and Collected Poems for Children. London: Faber.

Eliot, T.S. (1933). T.S. Eliot Selected Prose. Harmondsworth: Penguin.

Gubar, Marah. (2013). Risky business: talking about children in children's literature criticism. Children's Literature Association Quarterly, 38(4), 450-457.

Hollindale, Peter. (1997). Signs of Childness in Children's Books. Stroud: Thimble Press.

Maxwell, Glyn. (2012). On Poetry. Croydon: Oberon.

McGilchrist, Iain. (2009). The Master and His Emissary: The Divided Brain and the Making of the Western World. New Haven \& London: Yale University Press.

Nikolajeva, Maria. (2018). What is it like to be a child? Childness in the age of neuroscience. Children's Literature in Education, https://doi.org/10.1007/s10583-018-9373-7.

Nodelman, Perry. (2008). The Hidden Adult: Defining Children's Literature. Baltimore: Johns Hopkins University Press.

Pullinger, Debbie. (2017). From Tongue to Text: A New Reading of Children's Poetry. London: Bloomsbury.

Pullinger, Debbie and Whitley, David. (2017). The Poetry and Memory Project. http://www.poetryandm emory.com/.

Rose, Jacqueline. (1984). The Case of Peter Pan, or The Impossibility of Children's Fiction. London: Macmillan.

Rudd, David. (2018). Childness or child-less? Signs taken for wonders. Children's Literature in Education, https://doi.org/10.1007/s10583-018-9371-9.

Tatar, Maria. (2009). Enchanted Hunters: The Power of Stories in Childhood. New York: W.W. Norton \& Co.

Waller, Alison. (2010). Psychic barriers and contact zones: rereading rose and the rupture between child and adult. Children's Literature Association Quarterly, 35(3), 274-289. 